\title{
EFFECT OF PARTICLE SIZE OF GLIRICIDIA LEAVES AND SOIL TEXTURE ON N MINERALIZATION
}

\author{
B. C. Walpola ${ }^{1}$ and K. K. I. U. Arunakumara ${ }^{2}$
}

\begin{abstract}
Decline in soil productivity and environmental quality in the tropics have led to a search for new methods to sustain crop production via more efficient nutrient cycling. In tropical agricultural systems with limited access to fertilizers, plant residues are often used to meet the nutrient requirements of most of the crops. In this regard, leguminous residues are an important source of $N$ used in low input agricultural systems. The present laboratory investigation was conducted to elucidate the effect of the particle size of Gliricidia leaves $\left(S_{1}\right.$ $\left.\leq 0.5 \mathrm{~mm}, S_{2}=4 \mathrm{~mm}\right)$ and texture of soil $\left(T_{1}=\right.$ sandy clay loam, $T_{2}=$ loamy sand $)$ on $N$ mineralization. Results revealed that the pattern and the amount of $\mathrm{NH}_{4}{ }^{+}-\mathrm{N}$ released from two soil types were significantly $(P \leq 0.05)$ different. The highest amount of $\mathrm{NH}_{4}{ }^{+}{ }_{-} \mathrm{N}(82$ $\mathrm{mg} / \mathrm{kg}$ soil) was released at $21^{\text {st }}$ day of incubation from sandy clay loam soil treated with the particle size of $4 \mathrm{~mm}$. However, in the case of $\mathrm{NO}_{3}^{-}-\mathrm{N}$, loamy sand soil showed higher cumulative $\mathrm{NO}_{3}{ }^{-}-\mathrm{N}$ content than that of in sandy clay loam soil. The highest amount of $\mathrm{NO}_{3}{ }^{-}-$ $N(68 \mathrm{mg} / \mathrm{kg}$ soil $)$ was released at 21 st day of incubation from loamy sand soil treated with the particle size of $\leq 0.5 \mathrm{~mm}$. Results could be concluded that nitrogen mineralization of Gliricidia leaves were affected by the texture of the soil as well as the particle size of the Gliricidia leaves. The present findings therefore stress the importance of standardizing residue particle size as it determines the rate of $N$ mineralization in a given soil.
\end{abstract}

Key words: Decomposition, incubation, leguminous residues

\section{INTRODUCTION}

Farmers in developing countries can't afford the increasing prices of synthetic fertilizers. Incorporation of legume residues into the soil has thus been widely used in building up soils as legume residues conserve and recycle nutrients and protect the soil from erosion. Therefore, green manuring with legumes can minimize the amount of nitrogen fertilizer requirement substantially and thus could be considered as an economically viable management tool.

However, to be effective source of $\mathrm{N}$ for many crops, legumes should be able to supply sufficient amount of $\mathrm{N}$ in a synchronizing manner with the demand. Green manure decomposition and subsequent $\mathrm{N}$ release depend largely on residue quality and quantity, soil moisture and temperature, and specific soil factors such as texture, mineralogy and acidity, biological activity and the presence of other nutrients (Myers et al., 1994). The rate of decomposition of any organic material added to soil depends on the chemical composition of the material and the factors that affect the soil environment. The factors influencing residue decomposition in the soil can be broadly categorized as residue factors which include chemical composition $(\mathrm{N}$ concentration, $\mathrm{C}: \mathrm{N}$ ratio, lignin concentration, polyphenol concentration, etc.), particle size of the residues and indigenous microflora on the residues; soil factors which include soil water, temperature, $\mathrm{pH}$, aeration and available nutrients; and management factors such as rate of residue loading and method of

\footnotetext{
${ }^{1}$ Department of Soil Science, Faculty of Agriculture, University of Ruhuna, Mapalana, Kamburupitiya, Sri Lanka.

${ }^{2}$ Department of Crop Science, Faculty of Agriculture, University of Ruhuna, Mapalana, Kamburupitiya, Sri Lanka
} 
application. Though it is well understood that nitrogen release from residues can be regulated by altering or manipulating the factors which influence the mineralization of $\mathrm{N}$ from the residues, environmental factors such as temperature and moisture content cannot usually be altered in a given situation (location, soil type etc.).

Cited literature on nitrogen mineralization from organic residues has shown differences in the amounts of nitrogen released from the same residue in different soils (Thomsen and Olesen, 2000). Differences in nitrogen release may be attributed to adsorption of organic $\mathrm{N}$ by clays (Van Veen et al, 1985), increased aeration in sandy soils (Thomsen et al, 1999), different $\mathrm{C}$ to $\mathrm{N}$ ratios of microorganisms and micro fauna (Hassink, 1994; Hassink et al, 1994), and different populations of protozoa and nematodes present (Kuikman et al, 1991; Griffiths et al, 1994). The effect of particle size of crop residues on decomposition and dynamic of nutrients after incorporation into the soil has often been reported in the literature (Bending and Turner 1999). Despite many studies have been attempted to relate biochemical qualities of residues to decomposition and mineralization, the way in which physical qualities affect on mineralization is yet to be elaborated. In addition, some controversial reports in published literature stress the importance of reinvestigating the effect of particle size of crop residues on decomposition under given conditions.

Therefore the present study was undertaken

- To investigate the effect of particle size of Gliricidia leaves on nitrogen mineralization during decomposition.

- To investigate effect of soil type on nitrogen mineralization during the decomposition of Gliricidia leaves.

\section{MATERIALS AND METHODS}

\section{Climate and soil}

The experiment was conducted at the Faculty of Agriculture, University of Ruhuna, Mapalana, Kamburupitiya, Sri Lanka. According to the agro-ecological classification (Mapa et al., 1999), the region of investigation comes under agroecological region $\mathrm{WL}_{2}$ (low country wet zone). The climate of the area is tropical monsoonal (Mapa et al., 1999), with a warm wet period (April to June) and a relatively dry period (January to March). The area receives an annual rainfall of around $2500 \mathrm{~mm}$. The distribution of rain is bi-model. Annual mean air temperature of the area was $22-30{ }^{\circ} \mathrm{C}$ and the relative humidity is about $80 \%$. Two types of soil used in this experiment were sandy clay loam and loamy sand.

\section{Soil sampling}

Soil samples were collected randomly from several selected locations representing cultivated and non cultivated areas of Faculty of Agriculture, University of Ruhuna, Mapalana, Kamburupitiya, Sri Lanka. After removing the surface litter, soil sampling was performed from $0-15$ $\mathrm{cm}$ depth using an auger. They were then mixed thoroughly in order to make a composite sample.

\section{Treatments}

Leaves of the Gliricidia were oven dried at $60{ }^{0} \mathrm{C}$ for $72 \mathrm{hrs}$ and ground to the size of $\leq 0.5 \mathrm{~mm}\left(\mathrm{~S}_{1}\right)$ and also punched to get the particle size of $4 \mathrm{~mm}\left(\mathrm{~S}_{2}\right)$. Homogeneously mixed soil samples of $100 \mathrm{~g}$ were air dried and placed in air tight glass bottles. They were then kept in dark for two weeks prior to addition of plant materials for preincubation. During the period, soils in bottles were maintained at the moisture content to $50 \%$ of the field capacity (dry basis) by daily monitoring and adding water as needed. After two-week preincubation period, plant materials were added at the rate of 216 and $224 \mathrm{mg}$ 
respectively to sandy clay loam soil and loamy sand soil. Addition of plant materials was done on the base of the recommended mulch application rate of 5 tons dry matter per hectare, assuming that 1ha of soil $15 \mathrm{~cm}$ deep contains $2.31 \times 10^{6}$ $\mathrm{kg}$ of soil from sandy clay loam soil (bulk density of the soil $1.542 \mathrm{~g} / \mathrm{cm}^{3}$ ) and $2.23 \times 10^{6} \mathrm{~kg}$ of soil from loamy sand soil (bulk density of the soil $1.489 \mathrm{~g} / \mathrm{cm}^{3}$ ). Leaf particles were mixed thoroughly with the soil and incubated in the dark at room temperature $\left(25 \pm 1^{\circ} \mathrm{C}\right)$. Constant moisture content of the soil was maintained throughout the incubation period. Soil samples without plant materials were served as the control.

\section{Nitrogen mineralization}

$\mathrm{N}$ mineralization was determined using inorganic $\mathrm{N}\left(\mathrm{NH}_{4}{ }^{+}-\mathrm{N}\right.$ and $\left.\mathrm{NO}_{3}{ }^{-}{ }^{-} \mathrm{N}\right)$ concentration of the soil. Sub samples containing $10 \mathrm{~g}$ of soil, were extracted using $30 \mathrm{ml}$ of $2 \mathrm{M} \mathrm{KCl}$ at 2, 5, 7, 14, 21, $28,35,42,49,56,63$ and 70 days after the treatment and used to determine $\mathrm{NH}_{4}{ }^{+}-\mathrm{N}$ and $\mathrm{NO}_{3}{ }^{-}-\mathrm{N}$. $\mathrm{NH}_{4}{ }^{+}-\mathrm{N}$ contents according to Berthelot reaction (Searle, 1984) and sodium salicylate yellow color method (Bremner, 1960) respectively.

\section{Statistical analysis}

Data generated were subjected to analysis of variance (ANOVA) for a Factorial Design with four replicates using SAS software. Least significant difference at $\mathrm{P}$ $\leq 0.05$ was used to separate the means.

\section{RESULTS AND DISCUSSION}

The effect of particle size of Gliricidia leaves and soil type on nitrogen mineralization is shown in figure 1 and 2 . According to the results, the amount of $\mathrm{NH}_{4}{ }^{+}{ }_{-} \mathrm{N}$ released from two soil types was significantly $(\mathrm{P} \leq 0.05)$ different. Results further revealed that the releasing pattern of $\mathrm{NH}_{4}{ }^{+}-\mathrm{N}$ from two soil types was also distinctly different. Sandy clay loam soil showed higher cumulative $\mathrm{NH}_{4}{ }^{+}-\mathrm{N}$ content than that of in loamy sand soil. The highest amount of $\mathrm{NH}_{4}{ }^{+}-\mathrm{N}(82 \mathrm{mg} / \mathrm{kg}$ soil $)$ was released from sandy clay loam soil treated with the particle size $S_{2}(4 \mathrm{~mm})$ after 21 days of incubation. Whereas the highest amount of $\mathrm{NH}_{4}{ }^{+}-\mathrm{N}(72 \mathrm{mg} / \mathrm{kg}$ soil $)$ released from the $S_{1}(\leq 0.5 \mathrm{~mm})$ was recorded at 28 day of incubation.

The highest $\mathrm{NH}_{4}{ }^{+}-\mathrm{N}$ content $(58 \mathrm{mg} / \mathrm{kg}$ soil) released from loamy sandy soil was recorded at $42^{\text {nd }}$ day of incubation from $S_{1}$ followed by control (48 mg/kg soil) and $S_{2}$ $(32 \mathrm{mg} / \mathrm{kg}$ soil) respectively. The present higher extractable $\mathrm{NH}_{4}{ }^{+}-\mathrm{N}$ levels could result from stimulation of organic $\mathrm{N}$ ammonification or from depression of ammonium oxidation activity. Despite no significant $(\mathrm{P} \leq 0.05)$ differences were observed, $\mathrm{NH}_{4}{ }^{+}-\mathrm{N}$ content was found to be decreased in all the treatments during the final few days of the incubation. 

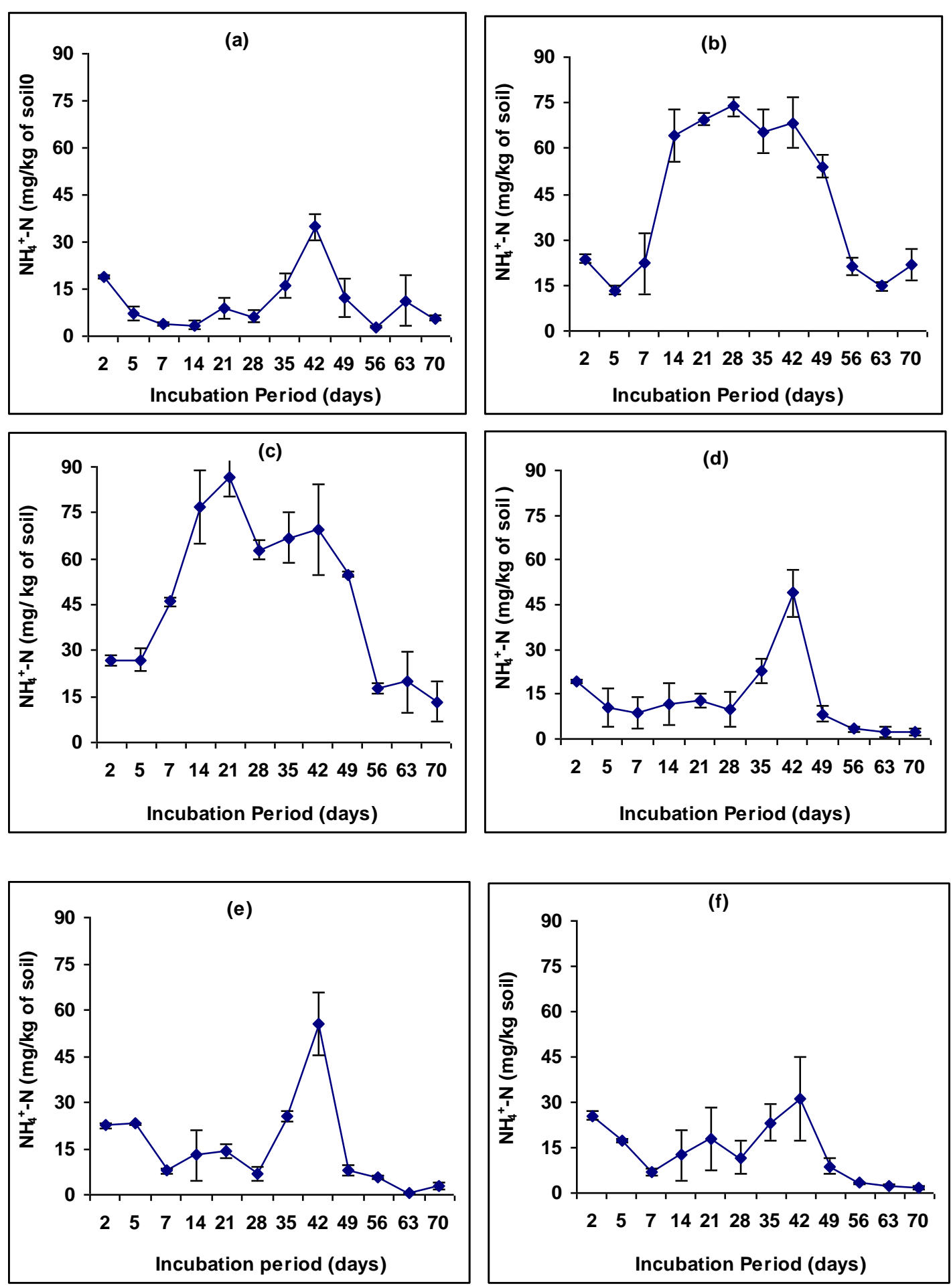

Figure 01: Release of $\mathrm{NH}_{4}{ }^{+}-\mathrm{N}$ from the soils amended with various sized particles of the Gliricidia leaves. For Sandy Clay Loam Soil (SCLS) (a) Control (without Gliricidia leaves), (b) SCLS treated with Gliricidia leaves of $\leq 0.5 \mathrm{~mm}$ particle size (c) SCLS treated with Gliricidia leaves of $4 \mathrm{~mm}$ particle size. For Loamy Sand Soil (LSS) (d) Control (without Gliricidia leaves), (e) LSS treated with Gliricidia leaves of $\leq 0.5 \mathrm{~mm}$ particle size, (f) LSS treated with Gliricidia leaves of $4 \mathrm{~mm}$ particle size. 
In the case of $\mathrm{NO}_{3}{ }^{-}-\mathrm{N}$, loamy sand soil showed higher cumulative $\mathrm{NO}_{3}{ }^{-}-\mathrm{N}$ content than that of in sandy clay loam soil. The highest amount of $\mathrm{NO}_{3}{ }^{-}-\mathrm{N}(68 \mathrm{mg} / \mathrm{kg}$ soil $)$ was released from loamy sand soil treated with $S_{1}$ after 21 days of incubation. According to the results, a slight increase in $\mathrm{NO}_{3}{ }^{-}-\mathrm{N}$ content was observed for both soil types until $14^{\text {th }}$ day of incubation followed by a reduction for all the treatments. From $35^{\text {th }}$ day onwards $\mathrm{NO}_{3}{ }^{-}$$\mathrm{N}$ content was found to be increased in all the treatments regardless the type of soil.

According to present findings, despite higher $\mathrm{NH}_{4}{ }^{+}-\mathrm{N}$ content was released in sandy clay loam soil (clay $28 \%$ ), the loamy sand soil (clay $9 \%$ ) has shown better performance in releasing $\mathrm{NO}_{3}{ }^{-}-\mathrm{N}$. Furthermore, in most of the occasions, small particles $\left(S_{1}\right)$ have shown better performance than large particles $\left(S_{2}\right)$ which may be due to their greater dispersion in the soil volume. The greater accessibility of the substrate and nutrients in them to microbial attack could also be contributed positively on rapid $\mathrm{N}$ mineralization observed in small particles. However, Jensen (1994) reported that the decomposition in the coarse particles is greater than that of in the fine particles. According to Jensen (1994), clay minerals could inhibit $\mathrm{N}$ mineralization during the early stage of decomposition which may be due to higher protection by clay minerals on microbial biomass and metabolites formed during the initial decomposition. Though blocking effect of clay minerals on decomposition is in agreement with Sims and Frederick (1970), they demonstrated that fine particles could accelerate the decomposing of plant materials than coarse particles. In fact microbial biomass and its products formed during the initial stage of decomposition could minimize biodegradation of small particles because of intimate mixing of residues with the soil. Present findings are in line with the results of Matus et. al. (2006) in which Wapril soil (loamy soil with $28.5 \%$ clay) showed a significantly higher $\mathrm{N}$ mineralization than Hualañé soil (sandy soil wit $11.9 \%$ clay).
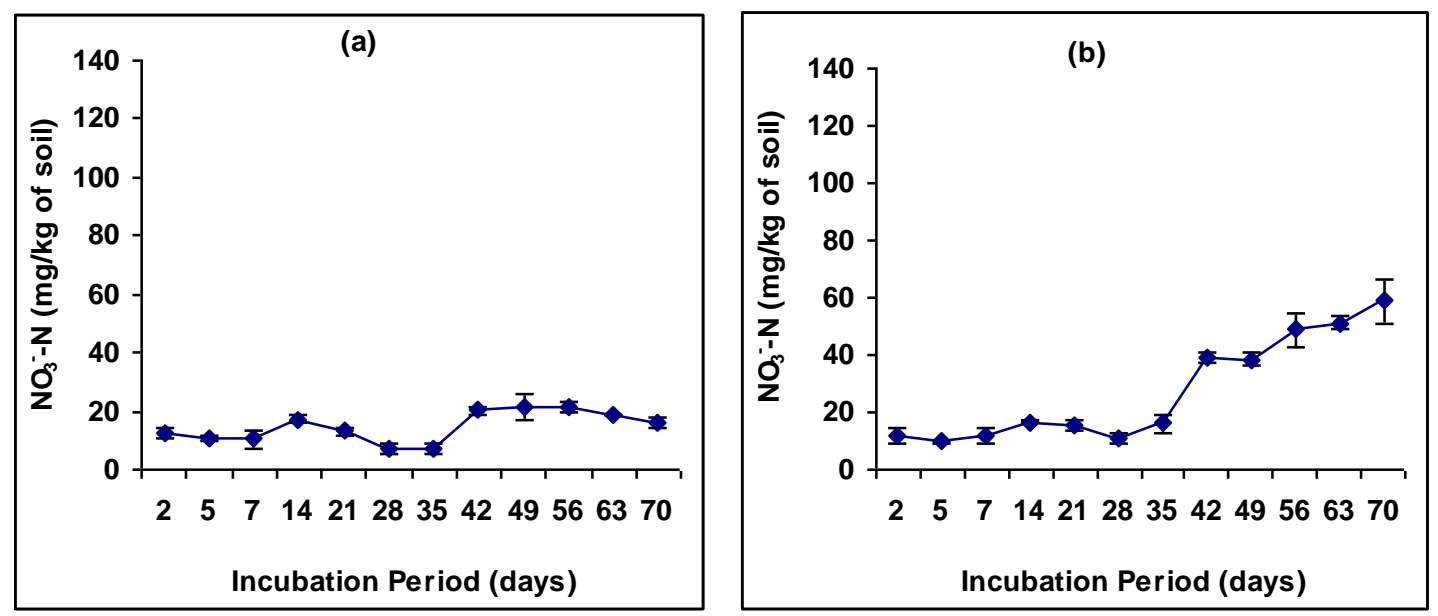

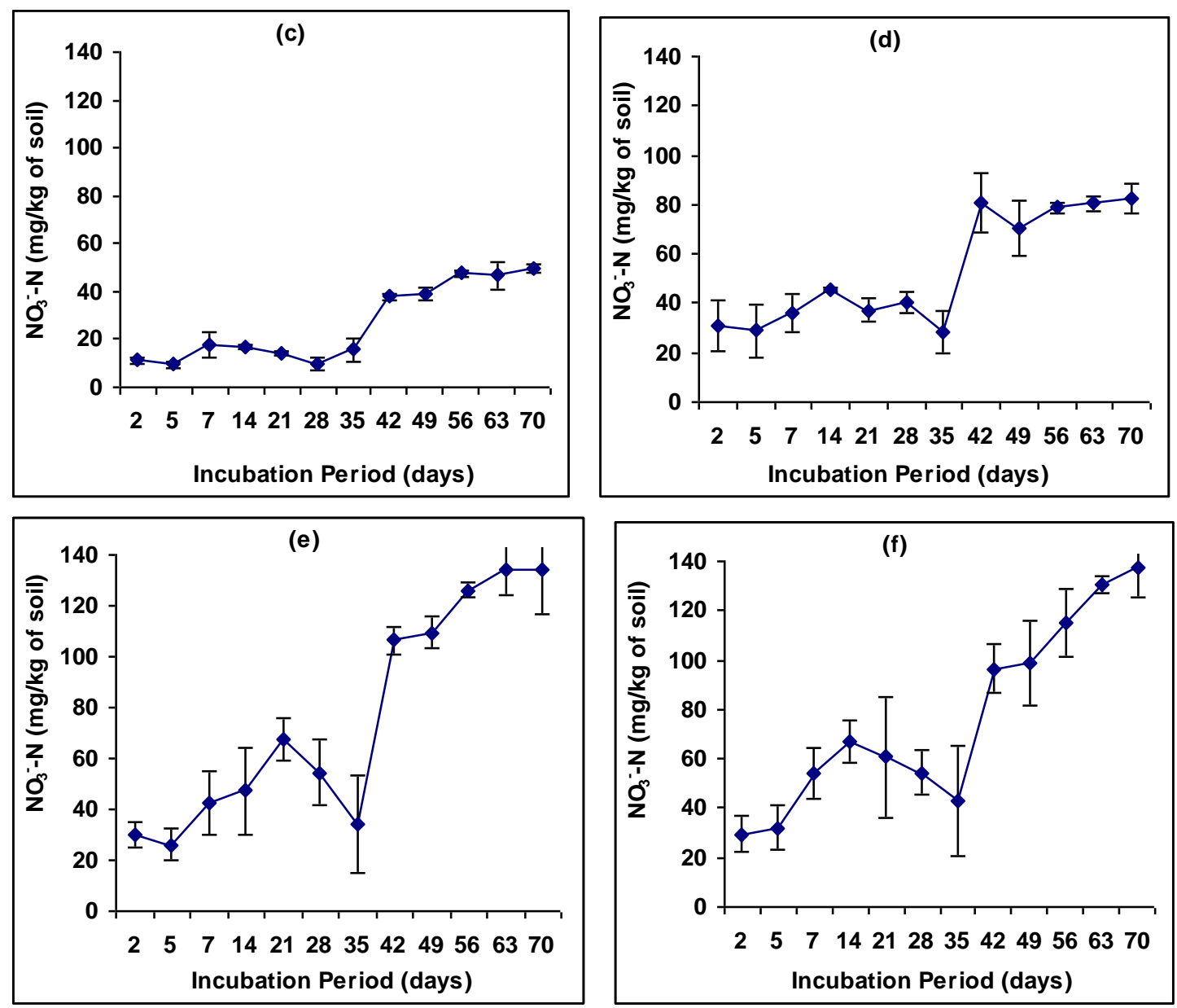

Figure 02: Release of $\mathrm{NO}_{3}{ }^{-} \mathrm{N}$ from the soils amended with various sized particles of the Gliricidia leaves. For Sandy Clay Loam Soil (SCLS) (a) Control (without Gliricidia leaves), (b) SCLS treated with Gliricidia leaves of $\leq 0.5 \mathrm{~mm}$ particle size (c) SCLS treated with Gliricidia leaves of $4 \mathrm{~mm}$ particle size. For Loamy Sand Soil (LSS) (d) Control (without Gliricidia leaves), (e) LSS treated with Gliricidia leaves of $\leq 0.5 \mathrm{~mm}$ particle size, (f) LSS treated with Gliricidia leaves $4 \mathrm{~mm}$ particle size.

\section{CONCLUSIONS}

Results could be concluded that nitrogen mineralization of Gliricidia leaves incorporated into soil was affected by the texture of the soil as well as the particle size of the leaves. In contrast, performance of small leaf particles was better than that of large particles. The present findings therefore stress the importance of standardizing residue particle size as it determines the rate of nitrogen mineralization in a given soil.

\section{REFERENCES}

Bremner, J. M. and C. S. Mulvaney (1982). Total nitrogen. In. A.L. Page (ed.) Methods of Soil Analysis. Part 2. Chemical and Microbiological Methods. $2^{\text {nd }}$ Edition. Amer. Soc. Agron. pp: 1149-1178. 
Bending, G. D., M. K. Turner and I. G. Burns (1998). Fate of nitrogen from crop residues as affected by biochemical quality and the microbial biomass. Soil Biology and Biochemistry 30(14),pp: 2055-2065.

Griffiths, B. S., M. M. I. Van Vuuren and D. Robinson (1994). Microbial grazer population in a ${ }^{15} \mathrm{~N}$ labelled organic residue and the uptake of residue $\mathrm{N}$ by wheat. European Journal of Agronomy. 3(4),pp:321-325.

Hassink, J. (1994). Effect of soil texture on the size of the microbial biomass and on the amount of $\mathrm{C}$ and $\mathrm{N}$ mineralized per unit of microbial biomass in Dutch grassland soils. Soil Biology Biochemistry. 26,pp:1573-1581.

Hassink, J., A. M. Neutel and P. C. Ruiter (1994). C and N mineralization in sandy and loamy grassland soils: The role of microbes and microfauna. Soil Biology and Biochemistry, 26,pp:1565-1571.

Jensen, E. S. (1994). Mineralization -immobilization of nitrogen in soil amended with low C: ratio plant residues with different particle sizes. Soil Biology and Biochemistry, 26,pp:519-521.

Kuikman, P. J., A. G. Jansen and J. A. Van Veen (1991). ${ }^{15} \mathrm{~N}$-nitrogen mineralization from bacteria by protozoan grazing at different soil moisture regimes. Soil Biology and Biochemistry, 23,pp:193-200.

Mapa, R. B., S. Somsiri and S. Nagarajah (1999). Soils of the wet zone of Sri Lanka. Soil Science Society of Sri Lanka, pp: 23-92.

Matus, F. J., J. B. Retamales and P. Sanchez (2006). Effect of particle size and quality of pruning wood residues of Asian Pear (Pyrus pyrifolia and Pyrus communis) on C-and $\mathrm{N}$ mineralisation in soils of contrasting textures. Revista de la Ciencia del Suelo y Nutrición Vegetal, Vol. VI No 1, enero-abril, pp:1-8.

Myers, R., J. K. Palm, C. A. E. Cuevas and I. U. N Gunatilleke (1994). Brossard the synchronization of nutrient mineralization and plant nutrient demand. In: Woomer P.L., Swift M.J., eds. The biological management of tropical soil fertility. Chichester, UK: Wiley-Sayce Publication, pp:81-116.

Searle, P.L. (1984). The Berthelot or Indophenol reaction and its use in the analytical chemistry of nitrogen: a review, Analyst, 109,pp: 549-568.

Sims, J. L. and L.R. Frederick (1970). Nitrogen immobilization and decomposition of corn residue in soil and sand as affected by residue particle size. Soil Science, 109,pp:355361.

Thomsen, I.K. and J.E. Olesen (2000). C and N mineralization of composted and anaerobically stored ruminant manure in differently textured soils. Journal of Agricultural Science, 135,pp:151-159.

Van Veen, J. A., J. N. Ladd and M. Amato (1985). Turnover of carbon and nitrogen through the microbial biomass in a sandy soil and a clay soil incubated with $\left[{ }^{14} \mathrm{C}(\mathrm{U})\right]$ glucose and $\left[{ }^{15} \mathrm{~N}\right] \quad\left(\mathrm{NH}_{4}\right)_{2} \mathrm{SO}_{4}$ under different moisture regimes. Soil Biology and Biochemistry, 17,pp:747-756. 